\title{
Review
}

\section{Radical Cosmopolitics. The Ethics and Politics of Democratic Universalism}

\author{
James D. Ingram
}

Columbia University Press, New York, 2013, 338pp., £23/\$32,

ISBN: 978-0231161107

Contemporary Political Theory (2015) 14, e1-e3. doi:10.1057/cpt.2014.30;

published online 4 November 2014

Contrary to Ingram's bold title, the starting point of Radical Cosmopolitics is quite conventional. It begins with a study of the origins of cosmopolitan thought - painting a portrait of the inability of cosmopolitan theory to reflect the increasingly global world. We are introduced to the two central characters of Ingram's work: the 'cosmopolite' and the 'hermit' - representing opposite strands of moral and political universalism. The former, being a member of an enlightened elite, sees his own mobility and cultural openness as a sign of the world to come, and as an ideal for others to strive towards - but he fails to see that he is speaking from a privileged place. By contrast, the hermit holds an ideal of a world where everyone's equal moral worth is recognised, but cannot identify how we can get there. His downfall is not that his political ideals are inadequate but that he refuses to have any. There is, Ingram tells us, a common theme running through these two types of cosmopolitanism - both construct 'the universal' as a response to particular political and social conditions of their time. The history of cosmopolitanism is a history of a struggle against real forms of particularism, inequality and exclusion.

The question that Ingram's book attempts to answer is: How can we imagine a cosmopolitan politics that is both truly universal and realistic? The question is an important one because, as Ingram reminds us, 'all politics is now in fact global' (p. 23). Ingram replies that universalism 'cannot be articulated directly' and 'should only be defined negatively'. Consequently, he argues that 'struggles against inequality and domination possess a universality that can form the core of a bottom-up cosmopolitics' (p. 213).

What then are Ingram's arguments in defence of his position? The basic assumption of any cosmopolitanism, he claims, is that morality is universal and human beings are equal. But Ingram questions the ability of existing strands of cosmopolitanism to achieve an account of 'the universal' consistent with their own principle of equality. If, he argues, we hold with Nussbaum that a substantive account of what is universally good can be achieved, then inevitably it will lead to an 
imposition of one set of values on others. When we attempt to implement a system of human rights from a position of power, we ignore a crucial tension between a rights regime, which is recognised as 'mine' or as 'imposed' (p. 261). Conversely, the Rawlsian account of the 'universal' through a system of abstract institutional rules leads, according to Ingram, to a 'hidden particularism' (p. 87). This is because an abstract account of the universal can easily become blind to particular types of inequality and oppression. However, Ingram's central target (or the whipping boy) is Kantian cosmopolitanism, which he ultimately views as the source of the current impasse. It was Kant, he claims, who at once prescribed a republican constitution as central to the Perpetual Peace, while authorising whatever state happens to exist 'however little it approximates the ideal' (p. 112).

The second 'part' of the book is devoted to attempting to rescue some sort of a vision of the universal. Ingram is convinced that we need such an account because the universal already manifests itself in the globalised world. The fact that philosophers have not come up with an adequate concept of the universal is not only a problem from a normative standpoint, but also in terms of being able to provide a theory that is relevant to the world we live in. Ingram thus seeks an alternative account of the universal by drawing on Bouden's notion of equality as an evaluative standard (p. 174). While norms and value systems might be culturally specific, he argues, every cultural, social or economic system can be evaluated from the perspective of whether or not it achieves its own standards of equality. One example he gives is the French schooling system, where increased standardisation leads to a reproduction of inequalities (p. 175). Ingram thus claims that such systems fail on their own accord.

What does this mean for cosmopolitanism? Well, Ingram claims that if we focus on universality, not as a substantive claim but an activity of challenging particular sources of inequality and exclusion, then perhaps we will come closer to a vision of a cosmopolitan politics. Ultimately, according to Ingram, cosmopolitanism cannot be realised by simply implementing someone's vision of the universal, but only through the universalisation of politics itself. 'Democracy, like cosmopolitan universalism, can then be understood as an infinitely repeatable claim against the limits, injustices and usurpations of any given set of institutions' (p. 202). A cosmopolitan vision of democracy, argues Ingram, should be understood as a transformation of existing peoples and institutions.

I agree with the general direction of Ingram's work and with some of his conclusions, but I find his account of cosmopolitanism too narrow and his view of politics too limited. First, by adapting a 'dialectic' account of the history of cosmopolitan thought, Ingram neglects strands of thought that do not fall within either of the extremes: for instance, various types of rooted or embedded cosmopolitanism (Erskine, 2008; Tamir, 1993). Ingram's argument is based on the artificial opposition between a type of abstract universalism, which ignores difference and specific visions of the universal, which carry with them the risk of usurping global 
politics. But Toni Erskine's idea of an 'embedded self' could address this opposition by showing that individuals have the capacity to act on principles that grant equal moral standing to outsiders. Erskine's solution also abandons the impartialist perspective as implausible. Instead, she suggests that the (transnational) communities of agents produce their own sets of practices, values and rules.

Second, when Ingram admits himself that politics constitutes a world of its own (p. 223), perhaps he doesn't fully realise that he sets a very high threshold for participating in politics. Similarly to Arendt, Ingram seems to be using the term 'world' to mean a sphere of human activity - namely, one characterised by freedom. This brings him to argue (after Arendt and Rancière) that a politics of human rights is about claiming those rights (p. 254). What about those who cannot claim their rights - the silent or the desolate? Isn't this vision of rights neglecting the very groups that the concept was meant to defend? Moreover, by shifting the focus from shared morality, values or capabilities, Ingram excludes all non-human animals from cosmopolitan considerations.

Radical Cosmopolitanism is a good read, and it provides a convincing perspective on the relationship between universalism and politics - one that isn't as onedimensional as those approaches that simply equate universalism with cosmopolitanism and dismiss particularism as nationalism. To the contrary, Ingram's vision of democratic universalism explicitly recognises that nationalism has done more to promote Kant's aims of equal freedom than the 'overt universalism of the cosmopolitan intellectual' (p. 59). In validating the role of various types of communities (not only the community of citizens) in challenging the limits of politics and forms of inequality, Ingram offers a more convincing account of how we could implement Arendt's call to transform moral rights into positive ones (p. 231). However, I haven't been able to shake off a sense of disappointment that Ingram's book fails to build and defend a positive account of 'cosmopolitics'. While he himself recognises that his approach may be seen to suffer from the same 'lack of realism' he accuses mainstream cosmopolitan theory of (p. 264), his defence remains unsatisfactory. Nevertheless, this book should be read by anyone who wants to give serious thought to the role of political theory in addressing global moral and political issues.

\section{References}

Erskine, T. (2008) Embedded Cosmopolitanism - Duties to Strangers and Enemies in a World of 'Dislocated Communities'. Oxford: Oxford University Press.

Tamir, Y. (1993) Liberal Nationalism. Princeton, NJ: Princeton University Press.

Michal Rozynek University of Edinburgh, Edinburgh, UK 